10.2478/v10103-012-0029-3

EWA KUSIDEŁ ${ }^{*}$, JOANNA GÓRNIAK ${ }^{* *}$

\title{
Transport Availability vs. Development of Poland's Regions
}

\begin{abstract}
The article discusses the issue of transport availability, taking into account road and rail infrastructure, as compared with socio-economic development in specific regions of Poland. The issue is studied from the theoretical and empirical point of view. The nature of the of the research is to use of existing methods for new dataset, namely the transport development level is estimated based on a composite indicator of development and degree of convergence among regions is estimated using classical regional convergence tests. The main goal of the study is to assess the degree of transport availability diversification among regions (voivodships) of Poland in comparison with their socio-economic development. The hypothesis assumes that there is strong correlation between transport availability and development of the regions and therefore similarity in the convergence inference.
\end{abstract}

\section{Introduction}

The issue of transport development evaluation in regions is frequently raised as one of components of comprehensive studies on regional economy, including those commenced in 1993 by the Gdańsk Institute for Market Economics and concerning investment attractiveness of voivodships. Among considered evaluation criteria was transport availability of regions, including

\footnotetext{
* Ph.D., University of Łódź

** University of Łódź
} 
their road and rail infrastructures, distance to airports, seaports, and border crossings.

The main objective of this study is to prove that there is a relationship between transport availability and economic growth (measured by the GDP per capita) in specific voivodships of Poland. If such a relationship exists, and taking into consideration numerous proofs of the lack of economic convergence among voivodships of Poland, an attempt will be made to verify a hypothesis that there is no convergence for a transport availability measure either. To that end, a synthetic indicator of transport availability of Poland's is built (using selected variables characterizing road and rail transport), which is discussed in the first chapter of this article. The verification of the convergence hypothesis applies classical convergence tests described in the second chapter and employed in the third chapter to examine spatio-economic cohesion.

The study covers years 2004 to 2009. The upper limit of the period is defined by data limitation of regional accounts - at the time of writing the paper the latest data on regional GDPs were available for 2009. The lower limit of the study period is the year of Poland's accession to the European Union, since when the cohesion policy has been carried out in Poland in order to attain economic, social, and spatial cohesion. Spatial cohesion is increased by eliminating barriers to accessibility of regions, in particular peripheral ones, by means of better communications, which is synthetically expressed by a transport availability measure constructed in this article.

\section{Transport Availability - the Essence, Issues, and Structure of a Composite indicator}

Transport infrastructure can be analysed from three points of view. Firstly, it ensures connections among territorial units. Secondly, it provides material conditions for carrying out production activity without which such activity would be impossible. Thirdly, it necessitates the presence of production activity preconditions associated with the presence of human capital, i.e. appropriate supply of labour, properly qualified and educated labour force (Wojewódzka-Król 2002, pp. 14-15). The role of transport infrastructure in economic development and its specificity result in the fact that any irregularities in the process of its development adversely affect the economy. Therefore, efficient and effective functioning of that area is vital from the economic point of view.

As a rule, transport structures of specific territorial units are influenced by numerous factors, which leads to considerable differences in their development 
levels. Elements that diversify the transport system arrangement include, among others: geographical situation, degree of urbanization, location of industrial and tourist centres, international cooperation, level of technical and technological development.

An analysis of the transport position may use specific or synthetic measures, such as a transport availability indicator enabling to assess a transport system from the spatial point of view. Simple indicators of provision with transport infrastructure include: the length of motorways and other roads (meant for the movement of motor vehicles) and railroads, number of railway stations and airports, time needed to reach the nearest transport hub of an interregional network. Complex indicators have a more complicated structure. The essence of complex transport availability indicators is that they take into account spatial interactions (i.e. distance to be covered, time and cost of travel). The attractiveness of a region can be assumed to increase along with its size and, in turn, decrease along with an increase in distance, time or cost of travel (Michałowska 2007, pp. 74-75).

\section{Transport Availability Indicator for Regions (Voivodships) of Poland}

The structure of a transport availability indicator is not unambiguous and may cause numerous problems. Researchers dealing with that phenomenon (e.g. Koźlak 2007; Rosik, Szuster 2008) tend to base their work on slightly different variables, which seems justified in both methodological and economic terms. In general, variables describing road, rail, air, and water transport may be verified.

This study attempts to build a synthetic indicator of transport availability for voivodships of Poland, taking into account different diagnostic variables (compare Table 1). Priority is given to variables related to road transport. The study considers one variable characterizing rail transport (the length of utilized railroads in $\mathrm{km}$ per 100 square $\mathrm{km}$ ). Thus, such an approach will contribute to an increase in the transport availability indicator for the Śląskie voivodship, where the density of railroad network is the highest in Poland.

In general, variables were selected based on the following premises:

- road transport is the most common mode of transport in Poland,

- inland water transport cannot function effectively in Poland due to the insufficient traffic capacity of rivers and irregularity of river traffic flow throughout the year,

- sea transport applies only to two regions (Pomorskie and Zachodniopomorskie), hence, application of variables that characterize that 
mode of transport would be irrational and discriminate against regions without access to the Baltic Sea,

- domestic air transport is of no particular importance as not all regions have passenger airports (the situation has slightly changed in the year of EURO 2012 - however, it is a year not covered by analyses in this article).

Table 1. List of diagnostic variables considered in the measurement of transport availability

\begin{tabular}{|l|l|l|}
\hline No. & \multicolumn{1}{|c|}{ Name of variable } & Conversion factor \\
\hline 1. & Public roads with hard surface & 100 square $\mathrm{km}$ \\
\hline 2. & National roads & 100 square $\mathrm{km}$ \\
\hline 3. & Provincial roads & 100 square $\mathrm{km}$ \\
\hline 4. & Poviat roads & 100 square $\mathrm{km}$ \\
\hline 5. & Communal roads & 100 square $\mathrm{km}$ \\
\hline 6. & Motorways & 100 square $\mathrm{km}$ \\
\hline 7. & Expressways & 100 square $\mathrm{km}$ \\
\hline 8. & Bridge-type structures on public roads (bridges, flyovers) & 100 square $\mathrm{km}$ \\
\hline 9. & Tunnels and underpasses on public roads & 100 square $\mathrm{km}$ \\
\hline 10. & Utilized railroads & 100 square $\mathrm{km}$ \\
\hline 11. & Regular bus transport lines (domestic) & 100 square $\mathrm{km}$ \\
\hline 12. & Individual motorization indicator & 1000 inhabitants \\
\hline 13. & Lorry number indicator & 1000 inhabitants \\
\hline 14. & Paid passenger transport & kilometer \\
\hline
\end{tabular}

Source: own work based on Central Statistical Office (CSO) data.

Variables listed in the above table have features of stimulants, and thus, it is expected that their increase will positively affect the synthetic variable characterizing transport availability. Nevertheless, an excessive increase in levels of variables specified in the final lines of Table 1 may contribute to an increase in an adverse phenomenon of transport congestion ${ }^{1}$ - hence, an increase in the specified diagnostic features will be desirable only to a certain limited extent. The calculation of the synthetic transport availability measure applied the development pattern method. The selection of diagnostic features was tested taking into account their universality, importance (Malina 2004, pp. 35-37), and variability. Moreover, two kinds of availability were considered: passenger transport availability and goods transport availability. In the case of both the indicators, several variables were identified characterizing both of them (those

\footnotetext{
${ }^{1}$ Transport congestion may be understood as overcrowding, overloading, accumulation. In other words, congestion is the occurrence of an excessive number of buyers or users of transport services at the same place and time (based on: Tundys B., 2008, pp. 128-129).
} 
were variables 1-10 and 13 for goods transport availability and, additionally, variables 11, 12, and 14 for passenger transport availability). Maps provided below present diversification of the synthetic availability indicator over the period of six years (2004-2009).

Map 1. Passenger transport availability indicator in 2004

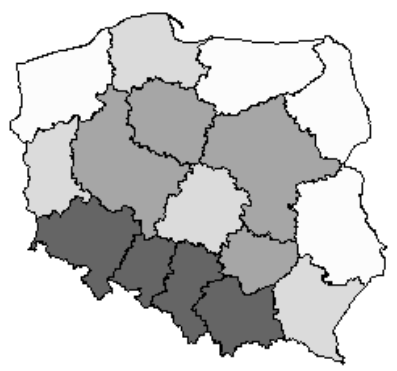

Map 3. Goods transport availability indicator in 2004

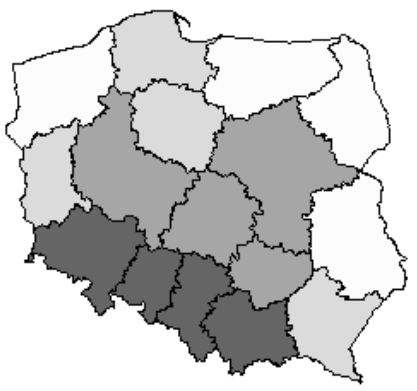

Map 2. Passenger transport availability indicator in 2009

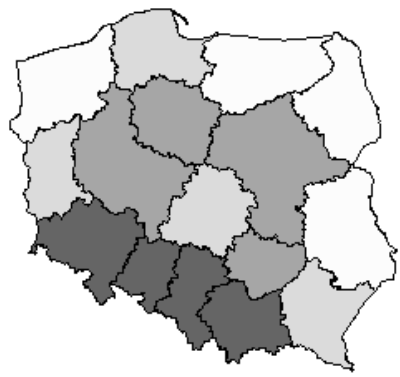

Map 4. Goods transport availability indicator in 2009

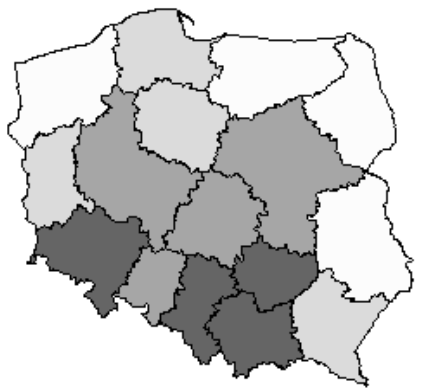

Source: own work based on Local Data Bank - Central Statistical Office (LDB - CSO) data.

The above maps indicate that regions with the highest indicator of transport availability include: Dolnośląskie, Małopolskie, and Śląskie (for both passengers and goods). The lowest passenger and goods transport availability indicator values characterize the following voivodships: Lubelskie, Podlaskie, Warmińsko-Mazurskie, and Zachodniopomorskie. At the same time, it can be observed that changes over the period of 2004-2009 (quartile-based) were minor - low mobility of the goods transport availability indicator provides premises to infer the absence of the indicator's convergence among the studied regions. 


\section{Regional Convergence - Types and Ways of Measurement}

In free translation, convergence means similarity or gathering. Convergence is a process in which various units, initially bearing no similarity, become closer and more similar to one another. In studies, subjects tend to be countries or regions (thus, the name: regional convergence). A term opposite to convergence is divergence, i.e. lack of similarity.

The concept of convergence was formed based on the theory of systems in the 1940s and 1950s. It developed rapidly in the 1980s. Initially, convergence studies consisted in analysing the theory of the socialist and capitalist systems' development becoming similar. Over time, researchers began to refer to the concepts of economic growth, systems of financial markets or lifestyles, consumption, state administration (Woźniak et al. 2009, p. 53).

An important moment for the convergence theory was identification of classical convergence. The following three types developed within that kind of convergence:

- $\beta$-type convergence,

- $\sigma$-type convergence,

- $\gamma$-type convergence.

The fundamental element of $\beta$-type convergence is the study of the so called catch-up effect. Furthermore, $\beta$-type convergence can be considered from two different points of view: absolute and conditional. Absolute $\beta$ convergence assumes that units pursue the same state of long-term balance, while the essence of conditional $\beta$-type convergence is the fact that specific units aim to achieve their own convergence levels.

$\sigma$-type convergence occurs when diversification of values of an analysed variable among countries or regions decreases in consecutive units of time. Diversification is examined by means of measures of variation (standard deviation, coefficient of variation) or concentration (e.g. Gini coefficient).

$\beta$ convergence is a necessary but insufficient condition for $\sigma$-type convergence to occur. That means that the occurrence of $\beta$-type convergence is not tantamount to the presence of $\sigma$-type convergence (Wolszczak-Derlacz 2007, p. 11).

$\gamma$-type convergence aims to inform whether a given country or region has changed its ranking in respect of an examined variable. In order to perform verification, each territorial unit is assigned a rank. The examination of that kind of convergence may use Kendall's rank coefficient of concordance or Pearson's coefficient. Values of Kendall's coefficient range from 0 to 1. Convergence will occur when the value of Kendall's coefficient is close to zero (Boyle, McCarthy 
1997, pp. 257-264). On the other hand, Pearson's coefficient ranges from -1 to 1 . When values of the coefficient are negative or insignificant, convergence occurs.

\section{Analysis of Spatio-Economic Convergence among Regions of Poland}

When convergence is discussed, researchers usually mean its economic dimension reflected in decreasing disproportions in measures that are based on the gross domestic product. However, the issue of convergence may be extended to cover numerous other aspects of life. In particular, the cohesion policy carried out within the framework of the EU regional policy strives to increase the levels of not only economic but also social and territorial (spatial) convergence. Social convergence means decreasing differences in human and social capital, and standard of living ${ }^{2}$. Spatial cohesion is increased by eliminating barriers to accessibility of regions, especially peripheral ones, through better communications and connections with centrally located areas ${ }^{3}$. This article studies two kinds of convergence:

- economic - measured using one of the basic measures of national income (regional income, in this case) determining economic development, i.e. the gross domestic (regional) product,

- spatial - measured by means of the synthetic transport availability measure (described in Chapter 1).

In the case of the GDP per capital, attention should be paid to significant differences in its value among specific voivodships of Poland - compare Maps 5-6. The gross regional product varies significantly among regions of Poland. A division into wealthier and poorer regions can be clearly observed. Regions characterized by significantly higher GDPs per capita are: Dolnośląskie, Mazowieckie, Śląskie, and Wielkopolskie provinces. Significantly lower GDPs per capita characterize regions located in the Eastern part of the country, i.e.: Lubelskie, Podkarpackie, Podlaskie, and Warmińsko-Mazurskie. Similarly to the transport availability indicator, there are no changes (quartile-based) in the arrangement of regions according to the GDP per capita - which is an argument against convergence of the GDP per capita among regions of Poland.

\footnotetext{
${ }^{2}$ They are measured by means of the unemployment rate or participation rate (employment rate) or indicators describing the standard of living, e.g. the HDI.

${ }^{3}$ Additionally, numerous other areas of convergence can be considered, of which the most important and very current, from the point of view of the EU strategy, is the convergence of sustainable development.
} 
Map 5. GDP per capita in Poland in 2004

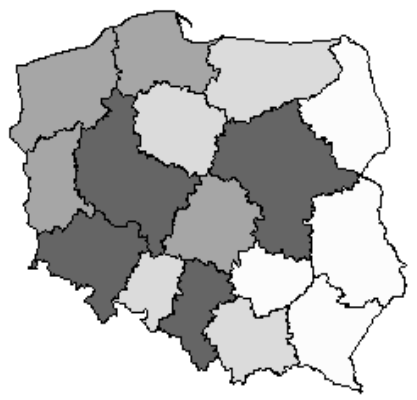

Map 6. GDP per capita in Poland in 2009

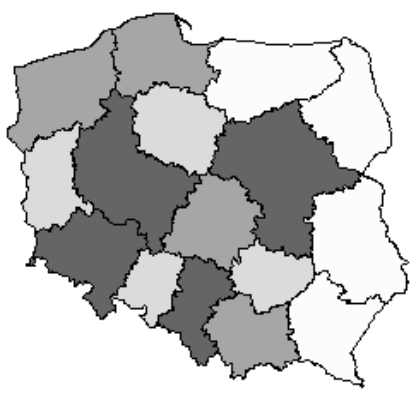

Source: own work based on LDB - CSO data.

There is a positive correlation of $0.5-0.6$ between variables characterizing transport availability and economic growth measured by the GDP per capita. It can be assumed that the studied variables (the GDP per capita and transport availability indicator) will exhibit the same tendency as to their convergence (i.e. the actual convergence or divergence). Based on the mere analysis of maps it can be pointed out that regions characterized by a higher level of transport availability indicator achieved a higher level of economic growth than those having a lower transport availability indicator.

In order to formally examine the occurrence of cohesion of (passenger and goods) transport availability and economic growth among specific regions, $\sigma$ type and $\gamma$-type convergence was used. For $\sigma$-type convergence (for which the measure of diversification was the standard deviation), it was concluded that there is no such convergence (for both passenger and goods transport availability as well as economic growth). It is impossible, however, to state the occurrence of divergence as the parameter of the temporal variable in the trend model matching the diversification graphs of variables is statistically insignificant. 
Figure 1. $\sigma$ convergence passenger transport availability

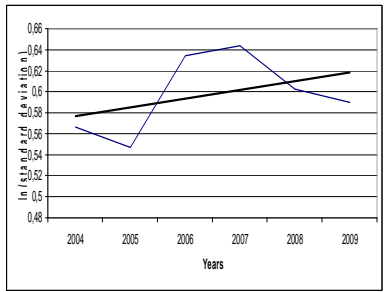

Figure 2. $\sigma$ convergence goods transport availability

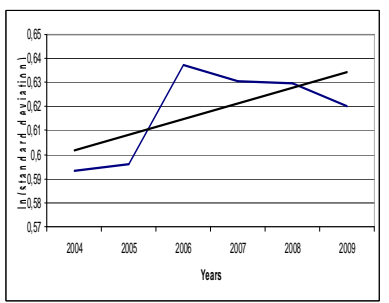

Figure 3. $\sigma$ convergence economic growth measured by GDP per capita

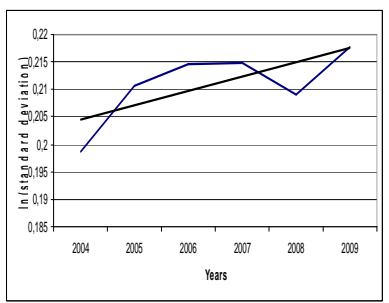

Source: own work based on CSO data.

In order to determine the occurrence of gamma-type divergence, Pearson's linear correlation coefficient was used. Correlation between the arrangement of voivodships in the first and last year of the analysis is high and statistically significant. That indicates the lack of changes in the arrangement of regions - i.e. the lack of gamma-type correlation - compare Table 2.

Table 2. Correlation for the arrangement of regions in two years of analysis: 2004 and 2009

\begin{tabular}{|c|c|c|}
\hline $\begin{array}{c}\text { Passenger transport } \\
\text { availability indicator }\end{array}$ & $\begin{array}{c}\text { Goods transport } \\
\text { availability indicator }\end{array}$ & $\begin{array}{c}\text { Economic growth measured } \\
\text { by GDP per capita }\end{array}$ \\
\hline 0.994 & 0.997 & 0.968 \\
\hline
\end{tabular}

Source: own work.

To sum up the methods applied to analyse the process of convergence, it can be said that the specified methods produced unanimous results based on which it can be stated that, taking into account both transport availability (for passengers and goods) and economic growth (measured by the GDP per capita), there was no convergence among regions of Poland in the 2004-2009 period. In consequence, the regions did not exhibit a tendency to become more similar in respect of the analysed variables.

\section{Conclusions}

Transport availability can be analysed at various geographical levels. This study takes into consideration the NUTS 2 territorial division - which, in the case of Poland, means the level of voivodships. The carried out study allowed to prove, in accordance with indications provided by literature, that the studied 
variables: transport availability indicators and economic growth measured by the GDP per capita show a mutual relationship. What is more, similar tendencies of changes in specific voivodships in respect of the analysed variables can be observed - regions characterized by high values of transport availability indicators (for passengers and goods) have higher GDPs per capita. A similar relationship occurs for less developed regions, i.e. those having lower values of passenger and goods transport availability indicators and low economic growth measured by the GDP per capita. The study proves the formulated hypothesis of the lack of convergence among regions in respect of (both types of) transport availability and GDP per capita.

Eventually, the conducted research indicates that there is a positive statistically significant correlation between economic well-being (measured by the GDP per capita) and transport availability (measured by the synthetic measure of development), while the analysis of convergence of both the variables proved that changes existing among regions in respect of those variables do not decrease. Particularly negative differences are observed for the Eastern Poland regions - whose weak position in terms of the GDP per capita and transport availability in 2004 did not improve in 2009. It ought to be recommended that special funds meant for the development of Eastern Poland in the 2007-2013 period be to a large extent allocated to infrastructural investments - due to their connection with economic growth as it is known that one of the main barriers to the development of less developed areas is the lack of modern transport infrastructure being among the fundamental conditions for development. Inadequately developed infrastructure adversely affects investment appeal of an area and the quality of life of its population. Therefore, appropriate development of transport infrastructure may prove to be the most important element of regional characteristics.

\section{References}

Bell G., Bowen P., Fawcett P. (1984). The business of transport. MacDonald \& Evans Ltd, Plymouth

Boyle G.E., McCarthy T.G. (1997). A simple measure of $\beta$-convergence, Oxford Bulletin of Economics and Statistics, 59, 2

Michałowska M. (Ed.), (2009). Efektywny transport - konkurencyjna gospodarka [Effective transport - competitive economy], Wydawnictwo Akademii Ekonomicznej im. Karola Adamieckiego w Katowicach, Katowice 
Michałowska M. (Ed.), (2009). Transport $w$ gospodarce opartej na wiedzy [Transport in knowledge-based economy], Wydawnictwo Akademii Ekonomicznej im. Karola Adamieckiego w Katowicach, Katowice

Malina A. (2004). Wielowymiarowa analiza przestrzennego zróżnicowania struktury gospodarki Polski wedtug województw [Multidimensional analysis of spatial diversification of Polish economy structure according to voivodships], Wydawnictwo Akademii Ekonomicznej w Krakowie, Kraków

Raport wykonany dla Ministerstwa Rozwoju Regionalnego [Report prepared for the Ministry of Regional Development]: T. Komornicki (Ed.), (2008). Opracowanie metodologii liczenia wskaźnika międzygatęziowej dostępności transportowej terytorium Polski oraz jego oszacowanie [Methodology of computing the intramodal transport availability indicator for the territory of Poland and its estimation], Warszawa

Rosik P., Szuster M. (2008). Rozbudowa infrastruktury transportowej a gospodarka regionów [Development of transport infrastructure and regional economy]. Politechnika Poznańska, Poznań, Poznań

Spiekermann K., Neubauer J. (2002). Accessibility and peripherality: concepts, models and indicators, Nordregio

Wojewódzka-Król K. (Ed.), (2002). Rozwój infrastruktury transportu [Development of transport infrastructure], Wydawnictwo Uniwersytetu Gdańskiego, Gdańsk

Wolszczak-Derlacz J. (2007). Wspólna Europa, różne ceny - analiza procesów konwergencji [Common Europe, different prices - analysis of convergence processes], Wydawnictwo CeDeWu, Warsaw

Woźniak M.G., Czuzhykov V.I., Lukianenko D.G. (2009). Konwergencja modeli ekonomicznych. Polska i Ukraina [Convergence of economic models. Poland and Ukraine], Wydawnictwo Fundacja Uniwersytetu Ekonomicznego w Krakowie, Kraków

Zeliaś A. (2000). Taksonomiczna analiza przestrzennego zróżnicowania poziomu życia w Polsce $w$ ujęciu dynamicznym [Dynamic taxonomic analysis of standard of living spatial diversification in Poland], Wydawnictwo Akademii Ekonomicznej w Krakowie, Kraków 


\title{
Streszczenie
}

\section{DOSTĘPNOŚĆ TRANSPORTOWA A ROZWÓJ POLSKICH WOJEWÓDZTW W ŚWIETLE ANALIZY KONWERGENCJI REGIONALNEJ}

\begin{abstract}
$W$ artykule omówiono problem dostępności transportowej z wyróżnieniem infrastruktury drogowej oraz kolejowej na tle rozwoju spoteczno-gospodarczego $w$ poszczególnych województwach $w$ Polsce. Zagadnienie to rozpatrywane jest zarówno $w$ aspekcie teoretycznym, jak $i$ empirycznym. Istota badania jest wykorzystanie istniejacych metod do nowego zestawu danych, a mianowicie poziom rozwoju transportu oszacowano na podstawie złożonego wskaźnika rozwoju, zaś stopień zbieżności pomiędzy regionami określono przy użyciu testów klasycznej konwergencji. Gtównym celem badania jest ocena stopnia zróżnicowania dostępności transportowej pomiędzy województwami $w$ Polsce $w$ porównaniu do ich rozwoju społeczno-gospodarczego. Hipoteza badawcza zaktada, że istnieje silna korelacja pomiędzy dostępnościa transportowa i rozwojem regionów, co pociaga za soba podobieństwo wniosków co do występowania konwergencji.
\end{abstract}

